Bangladesh J. Bot. 44(1): 1-7, 2015 (March)

\title{
DECOMPOSITION OF AVICENNIA MARINA (FORSK.) VIERH. FOLIAGE UNDER FIELD AND LABORATORY CONDITIONS IN THE BACKWATERS OF KARACHI, PAKISTAN
}

\author{
Seema Shafique, Pirzada JA Siddiqui*, RA Aziz, SS Shaukat ${ }^{1}$ and Z Farooqui ${ }^{2}$ \\ Center of Excellence in Marine Biology, University of Karachi, Karachi-75270, Pakistan
}

Key words: Avicennia marina, Decomposition, Leaf litter, Mangrove

\begin{abstract}
The fate of leaf litter decomposition of Avicennia marina (Forsk.) Vierh. was found higher under field aerobic condition (FAC) while the fate was lowest under laboratory anaerobic condition (LAAC). The time required for the loss of half of the initial day weight $\left(\mathrm{t}_{50}\right)$ was 48, 55, 98 and 110 days for aerobic condition (AC), field micro-aerobic condition (MAC), laboratory aerobic condition (LAC) and LAAC, respectively. Total nitrogen content of the decomposing litter increased by contrast, total organic carbon decreased during decomposition. Consequently, carbon to nitrogen ratios declined with time during decomposition. Repeated measure design showed that weight loss, total nitrogen and total organic carbon vary significantly under all four conditions with respect to elapsed time ( $p<0.001$; Wilks'Lambda $=0.02,0.003,0.02$, respectively at $\mathrm{p}<0.001)$. The study concludes that mangrove litter has an initial rapid phase of decomposition and the variable decay rates depend on the degree of exposure/submergence of litter in water, the pressure of detrivores, and the oxygen level in the given niche of mangrove forest.
\end{abstract}

\section{Introduction}

Mangrove swamps were known as one of the highly productive ecosystems of the world with regard to gross primary productivity and litter production (Kristensen et al. 2008, Bouillon et al. 2008, Alongi 2009). Mangroves are highly valued for their services to ecosystem, for example, in soil building, coastal protection, and as habitat and nursery grounds for many organisms (Odum and Helod 1975). Mangrove detritus system plays a key role in providing energy and organic and inorganic matter to the estuarine and coastal ecosystem (Jennerjahn and Ittekkot 2002, Mfiling et al. 2005) where it is available to detritivores (Goulter and Allaway 1979). Freshly fallen litter in water or on the sediment surface is either transferred through tidal currents to the adjacent water bodies or accumulated as peat and buried under forest sediments. Hence, it is evident that mangrove litter decomposes under variable conditions in nature such as, aerobic, micro-aerobic and anaerobic conditions.

The assessment of litter decomposition is an important tool for the analysis of ecosystem function. Mangrove litter decay and re-mineralization builds up soil organic matter which is a critical biogeochemical process in this ecosystem (Dick and Osunkoya 2000, Dick and Streever 2001). In mangrove litter production and decomposition is species specific and is governed by a number of climatic, physicochemical and biologial processes (Peterson and Cummins 1974, Howard and Howard 1979, Qasim et al. 1986, Stewart and Davies 1989). Decomposition of litter is also affected by $\mathrm{C}: \mathrm{N}$ ratio, initial nutrient levels and lignin (lignocellulose) content of litter (Pahalawattarachichi and Amarasinghe 1997). The litter decomposition varies geographically owing to the changes in controlling conditions from place to place (Sessegolo and Lana 1991).

*Author for correspondence. < jamal.siddiqui@yahoo.com>. ${ }^{1}$ Institute of Environmental Studies, University of Karachi, Karachi 75270, Pakistan. ${ }^{2}$ Institute of Marine Sciences, University of Karachi, Karachi 75270, Pakistan. 
Previous report on mangrove leaf decomposition in the Sandspit backwater, Karachi Pakistan was conducted by Siddiqui and Qasim (1988). The study described the decomposition in litter bags laid on the sediment surface. This essentially provides only a semi-aerobic condition in the decomposition of leaf- litter. Not all of the litter produced in mangroves decompose under semiaerobic condition, and that a reasonable part of detritus is transferred to adjacent waters where it will decompose aerobically. The litter that accumulates under the ground decomposes an-aerobically. Therefore, the present study was undertaken to examine litter decomposition under different environmental conditions mimicking aerobic, micro-aerobic and anaerobic, in field and laboratory experiments.

\section{Materials and Methods}

The Sandspit backwater ( $24^{\circ} 50^{\prime} \mathrm{N}$ and $66^{\circ} 56^{\prime} \mathrm{E}$ ) is connected to the Arabian Sea through Manora channel. During high and low tides, mangrove (Avicennia marina (Forsk.) Vierh. forest periodically receives an average volume of about 3.4 million $\mathrm{m}^{3}$ of seawater which inundates the backwater area through the Manora channel during each tidal cycle. The backwater also receives discharge from the Lyari River, a continuous source of fresh water carrying with domestic and industrial effluents.

Litter decomposition was studied using litterbag technique (Fell et al. 1984). Yellow senescent leaves were handpicked from the trees during July, 1999 and washed with tap water; blot dried and then used as initial material in all decomposition experiments. The decomposition experiment was carried out both in the field and laboratory under different conditions. For field experiment whole dry leaves (50 g in each bag) were placed in 30 nylon bags $\left(40 \times 60 \mathrm{~cm}, 1 \mathrm{~mm}^{2}\right.$ mesh size) and incubated in the field as: (i) Fifteen bags were laid on sediment surface under mangrove canopy giving a micro-aerobic condition (MAC) for decomposition and (ii) another set of 15 bags was suspended vertically in the channel water providing aerobic decomposing condition (AC). Net bags for laboratory experiment were similarly prepared and incubated as: (i) One set of 15 bags was incubated in tanks containing well aerated seawater providing laboratory aerobic condition (LAC) and (ii) another set of 15 bags was incubated in seawater under anaerobic condition (LAAC) in anaerobic jars. Triplicate bags were randomly selected and recovered from the field and laboratory after an incubation period of 7, 14, 30, 60 and 120 days. Decaying leaves were removed from the bags and washed, blot dried and weighed wet. Material was dried at $70^{\circ} \mathrm{C}$ for $48 \mathrm{~h}$ and the weight recorded separately to calculate weight loss using the following equation: Weight loss $(\mathrm{g} \%)=$ [initial weight (dry) - weight of the content of the bag $($ dry)]/[initial weight $($ dry $) \times 100]$. The dried recovered material was ground and stored for estimation of total organic carbon and total nitrogen using chromic acid wet oxidation method (Strickland and Parson 1972) and Micro-Kjeldal distillation method (Hawk et al. 1954), respectively.

Linear regression was used to determine the relation between weight loss and elapsed time. A repeated-measures design was used to determine the effect of experimental conditions (AC, MAC, LAC and LAAC) and time elapsed on weight loss and change in total nitrogen and total organic carbon during decomposition period using SPSS Ver.10.

\section{Results and Discussion}

The results showed that rate of mangrove leaf decomposition vary with the experimental conditions. Decomposition occurred significantly $(\mathrm{p}<0.001)$ faster rate in the field experiments $(1.16 \mathrm{~g} / \mathrm{day}(\mathrm{AC}), 1.04 \mathrm{~g} / \mathrm{d},(\mathrm{MAC})$ than in the laboratory experiments $(0.75 \mathrm{~g} / \mathrm{d}$, (LAC) and 0.53 $\mathrm{g} / \mathrm{d}$, (LAAC). Although the weight loss due to decomposition increased with time under all four 
conditions (Fig. 1), the time required for 50 per cent decomposition of the initial material (half lives, $\left.t_{50}\right)$ was significantly different $(p<0.001$, Table 1$)$. The repeated-measures design indicates that the pattern of total weight loss of mangrove litter was also significantly different under field (AC and MAC) and laboratory (LAC and LAAC) experimental conditions ( $<<0.001$; Wilk's Lambda $=0.02 \mathrm{p}<0.001)$. The fast or aerobic decomposition rates $(\mathrm{AC}$ and LAC) were significantly different $(\mathrm{p}<0.001)$ from slow decomposition rates under micro- and anaerobic conditions (MAC and LAAC).

(i)

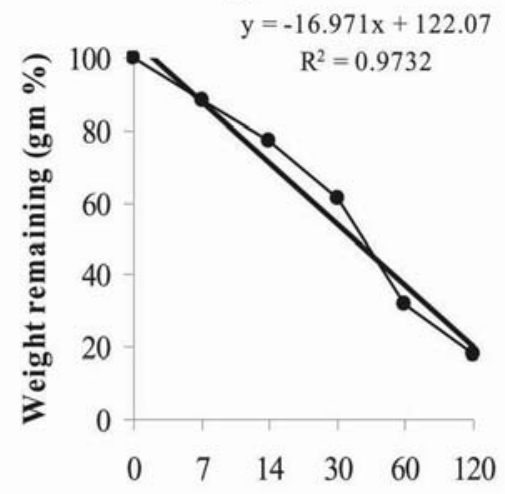

(iii)

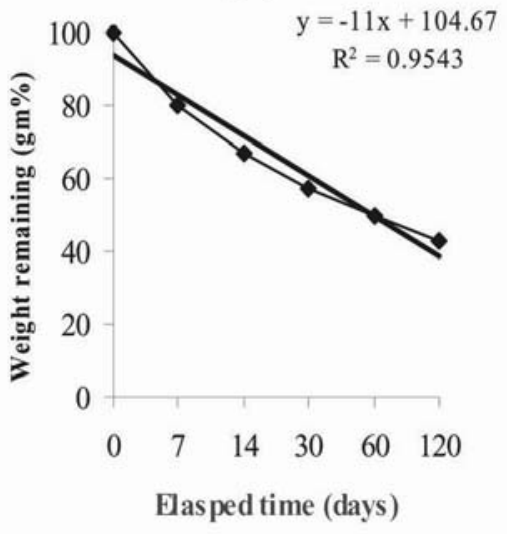

(ii)

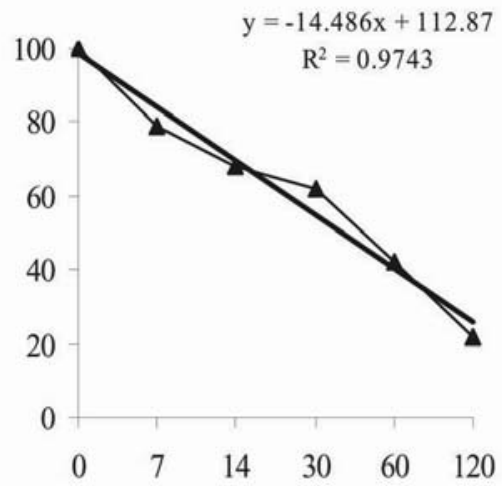

(iv)

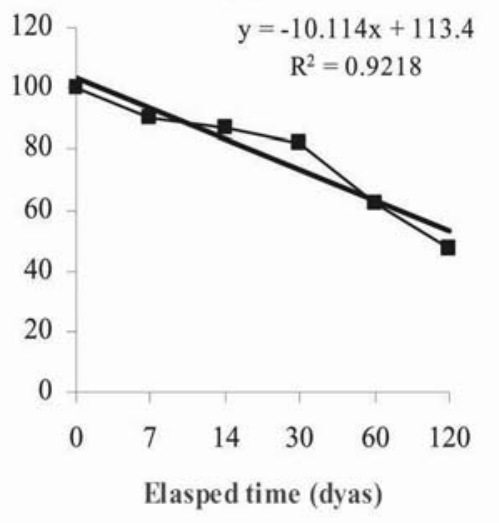

Fig. 1. Weight remaining (g\%) in decomposition leaves of A. marina under different conditions: (i) AC: Field aerobic; (ii) MAC: Field micro-aerobic; (iii) LAC: Laboratory aerobic; and (iv) LAAC: Laboratory anaerobic conditions.

Table 1. Values of decay constant $\left(K^{-1}\right)$, regression coefficient $\left(R^{2}\right)$ and half lives $\left(t_{50}\right)$ days for the decomposition of mangrove leaves $A$. marina at laboratory and field conditions.

\begin{tabular}{lccc}
\hline Conditions & Decay constant $\mathrm{Kd}^{-1}$ & Value of $\mathrm{R}^{2}$ & $\left(\mathrm{t}_{50}\right)$ half life \\
\hline Field aerobic condition & 0.1429 & 0.9743 & 48 \\
Field micro-aerobic condition & 0.1261 & 0.9732 & 55 \\
Laboratory aerobic condition & 0.0062 & 0.9543 & 98 \\
Laboratory anaerobic condition & 0.0070 & 0.9218 & 110 \\
\hline
\end{tabular}


A large proportion of litter produced in mangrove environment washes off into the adjacent waters (Austin 1971), some of which either remains on the sediment surface or buried under sediment and hence provides variable conditions for decomposition. The litter decomposed on the upper sediment layer experiences semi-aerobic conditions and periodic submergence in water by tidal inundation. Leaf litter in water column decomposes under continuous submergence and oxygenic condition. On the other hand, accumulated litter under sediment is subjected to anaerobic condition. The conditions used in the present investigation mimics the varied conditions prevailing in the nature. Field experiments provide aerobic (FAC) and micro-aerobic (MAC) conditions whereas anaerobic condition was established in the laboratory (LAAC). However, laboratory aerobic condition (LAC) replicates the field aerobic conditions except that it excludes herbivores. The low decay rate under LAC may be due to the exclusion of some of the consumers $\left(<1 \mathrm{~mm}^{2}\right)$, such as, isopods, polycheates, flatworms, nematodes, insect larvae, some gastropods and crabs which play a significant role in the initial stages of decomposition (Robertson 1986, Camilleri 1992). Similarly, very low decomposition rate observed in LAAC may be due to the lack of both oxygen and herbivores.

The decay pattern under all four conditions was similar, that is, rapid early losses followed by slow and steady decrease in the late decomposition phase. The initial rapid decrease in the total mass of litter may be related to the leaching of soluble organic and inorganic material (Steinke et al. 1983, Alongi et al. 1989) and also to the effect of herbivores (as mentioned above) in the early phase of decomposition. Leaves suspended in channel water decomposed at much faster rate compared to the leaves laid on the mud surface. Continuous submergence in water may have caused faster leaching of organic and inorganic materials (Albright 1976, Hoq et al. 2002, Mfiling et al. 2005). This also supports previously reported data that the degree of exposure of detritus to water column determine the rate of decomposition, i.e., leaves in low inter-tidal region, which is inundated by tides daily decompose at a much greater rate than those in the high inter-tidal forest which is inundated by tidal waters less frequently (Twilley et al. 1986, Holmboe et al. 2001).
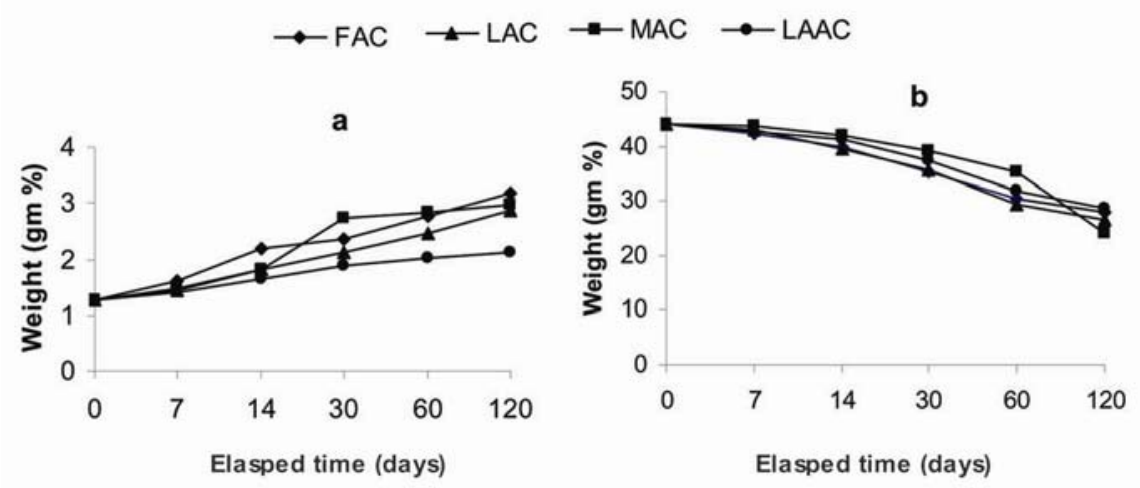

Fig. 2. Change in weight (g\%) of total organic nitrogen (a) and total organic carbon (b) in decomposing leaves of A. marina under four different conditions. AC: Field aerobic; MAC: Field micro-aerobic; LAC: Laboratory aerobic; and LAAC: Laboratory anaerobic conditions.

The total nitrogen content of decomposing liter increased with time. The initial low nitrogen value of mangrove leaves $1.25 \mathrm{~g} \%$ was increased up to $3.18 \mathrm{~g} \%$ during decomposition in 120 days. The increases in the total nitrogen content under aerobic condition were significantly higher $(\mathrm{p}<0.001$; Wilk's Lambda $=0.00 \mathrm{p}<0.001)$ compared to micro-aerobic and anaerobic conditions 
in both field and laboratory experiments (Fig. 2). Total organic carbon content of decomposing litter showed a decreasing trend with time (Fig. 2). The reduction in carbon was slow initially and progressed rapidly after 14 days of incubation under all conditions. The initial carbon content (44.17 g\%) of senescent leaves reduced significantly ( $<<0.001)$ to $27.80,24.28,26.68$ and 28.64 g\% under AC, MAC, LAC, and LAAC, respectively (Wilk's Lambda $=0.02 \mathrm{p}<0.001$ ). Reduction of carbon content appears to have no effect to incubation condition. Carbon to nitrogen ratio (C : N) of decomposing litter decreased with time. High initial C : N ratio (35.33) of senescent (yellow) mangrove leaves reduced significantly to values as low as 8.80 (AC), 8.13 (MAC), 11.02 (LAC) and 13.67 (LAAC) in 120 days (Fig. 3).

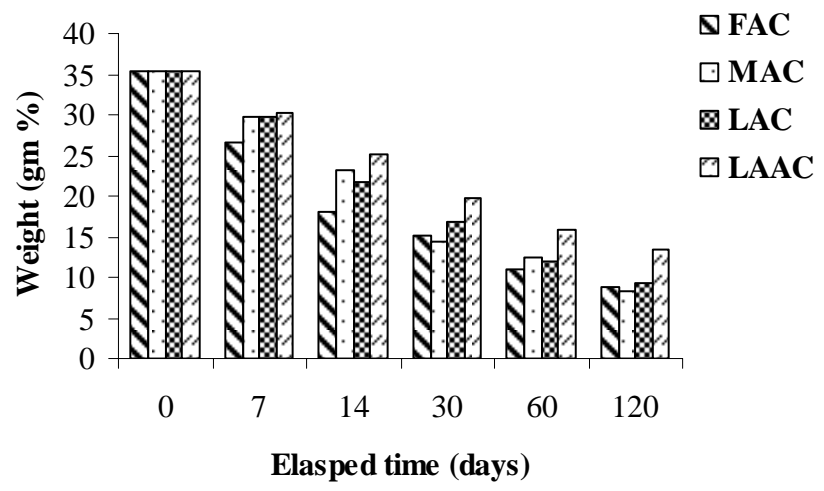

Fig. 3. Changes in $\mathrm{C}: \mathrm{N}$ with time in A. marina leaves decomposing under four different conditions. AC: Field aerobic; MAC: Field micro-aerobic; LAC: Laboratory aerobic; and LAAC: Laboratory anaerobic conditions.

The increases in nitrogen content during decomposition are generally due to the microbial colonization of the decaying litter (Alongi et al. 1989). Nitrogen enrichment lowers $\mathrm{C}: \mathrm{N}$ which is an indicator of nutritional value and index of chemical alteration (Fell and Master 1980, Siddiqui and Qasim 1988, Mfiling et al. 2002). Immobilization of nitrogen as microbial protein (Fell and Master 1980, Tam et al. 1990) occurs when initial C : N values are higher than $25: 1$ (Parnas 1975).

The present study indicates that mangrove litter decomposes at variable rate in different environmental situations. For example, 55\% more litter is lost in the field aerobic condition compared to litter decomposed aerobically in laboratory experiment. Similarly, $96 \%$ more litter is decomposed under field micro-aerobic condition compared to anaerobic laboratory condition. This can clearly be attributed to the effect of variable grazing pressure and oxygen availability for decomposition under different conditions tested. In brief, it is noted that (i) the mangrove litter has an initial rapid phase followed by the slower phase of decomposition, (ii) the nutritive quality of litter enhances during decomposition process, and (iii) the rate of decomposition is dependent on the degree of exposure/submergence of litter in water, the pressure of detrivores, and the oxygen level in the given niche of mangrove forest.

\section{Acknowledgements}

The authors are grateful to Commander, PNS Himalaya (Manora) for providing excess to mangrove forests falling in their area. First author (SS) thankfully acknowledges the receipt of Research Fellowship from the Center of Excellence in Marine Biology, University of Karachi, Pakistan. 


\section{References}

Albright LJ 1976. In situ degradation of mangrove tissues. New Zealand J. Mar. and Freshwater Res. 10: 385-389.

Alongi DM 2009. The energetics of mangrove forest. Springer press. p. 216.

Alongi DM, Sasekumar A, Tirendi F and Dixon P 1998. The influence of stand age on benthic decomposition and recycling of organic matter in managed mangrove forests of Malaysia. J. Exp. Mar. Biol. Ecol. 225: 197-218.

Alongi DM, Boto KG and Tirendi F 1989. Effect of exported mangrove litter on bacterial productivity and dissolved organic carbon fluxes in adjacent tropical near shore sediments. Mar. Ecol. Prog. Ser. 56: 133144.

Austin HM 1971. A survey of the Icthyofauna of the mangrove of western Puerto Rico. Caribbian J. Sci. 11(3-4): 27-39.

Bouillon S, Borges AV, Castaneda-Moya E, Diele K, Dittmar T, Duke NC, Kristensen E, Lee SY, Marchand C, Middelburg JJ, Rivera-Monroy V, Smith TJ and Twilley RR 2008. Mangrove production and carbon sink: A revision of global budjet estimates. Global Biogeochemical cycles 22, GB2013, dio:10.1029/2007GB003052.

Camilleri JC 1992. Leaf litter processing by invertebrates in a mangrove forest in Queensland. Mar. Biol. 114: 139-145.

Dick RM and Streever WJ 2001. Decomposition of Avicennia marina on an iron-smelling slag substance. Australian Ecol. 26: 127-131.

Dick TM and Osunkoya OO 2000. Influence of tidal restriction floodgates on decomposition of mangrove litter. Aqu. Bot. 68: 273-280.

Fell W, Master IM and Eiegert RG 1984 Litter decomposition and nutrient enrichment. In: SC Snedaker and JG Snedaker (eds). The mangrove ecosystem: Research methods. UNESCO, Paris. 239-251.

Fell JW and Master IM 1980. The association and potential role of fungi in mangrove detrital systems. Bot. Mar. 23(4): 257-263.

Goulter PFE and Allaway WG 1979. Litter fall and decomposition in a mangrove stand, Avicennia marina (Forsk.) Vierh. in Middle Harbour, Sydney. Australian J. Mar. and Freshwater Res. 30: 541-546.

Hawk BP, Oser LB and Summerson HW 1954. Practical physiological chemistry. McGraw Hill Book Co. London.

Holmboe N, Kristensen E and Andersen FO 2001. Anoxic decomposition in sediments from a tropical mangrove forest and the temperate wadden sea: Implications of $\mathrm{N}$ and $\mathrm{P}$ addition experiments. Estuar. Coast. and Shel. Sci. 53(2): 125-140.

Hoq ME, Islam ML, Paul HK, Ahmed SU and Islam MN 2002. Decomposition and seasonal changes in nutrient constituents in mangrove litter of Sundarbans mangrove, Bangladesh. Ind. J. Mar. Sci. 31(2): 130-135.

Howard PJA and Howard DM 1979. Relationship of decomposing litter in relation to temperature and moisture. Oikos 33: 475-465.

Jennerjahn TI and Ittekkot V 2002. Relevance of mangroves for the production and deposition of organic matter along tropical continental margins. Naturwissenschaften 89(1): 23-30.

Kristensen E, Bouillon S, Dittmar T and Marchand C 2008. Organic carbon dynamic in mangrove ecosystem: A review. Aquat. Bot. 89: 201-209.

Mfiling PR, Mezian T, Bachok Z and Tsuchiya M 2005. Litter dynamic and particulate organic matter out welling from a subtropical mangrove in Okinawa Island, South Japan. Estuar. Coast. and Shel. Sci. 63: 301-313.

Odum WE and Helad EJ 1975. The detritus based food webs of an estuarine mangrove community. Estuar. Res. 1: 265-286.

Pahalawattarachchi V and Amarasinghe MD 1997. Leaf litter composition and changes in leaf $\mathrm{C}: \mathrm{N}$ ratio in the mangals of Negombo Lagoon. Sri Lanka. J. Aquat. Sci. 2: 29-41. 
Parnas H 1975. Model for decomposition of organic material by microorganisms. Soil Biol. Biochem. 7: 161169.

Peterson RC and Cummins KW 1974. Leaf processing in a Woodland stream. Fresh water Biology 4: 343368.

Qasim R, Barkati S, Siddiqui PJA and Ilyas M 1986. Biochemical composition of mangrove (Avicennia marina) foliage. Pakistan J. Sci. and Ind. Res. 29: 37-39.

Robertson AI 1986. Leaf burying crabs: Their influence on energy flow and export from mixed mangrove forests (Rhizophora spp.) in northeastern Australia. J. Exp. Mar. Biol. and Ecol. 102: 237-48.

Sessegolo GC and Lna PC 1991. Decomposition of Rhizophora mangle, Avicennia schaueriana and Laguncularia racemosa leaves in a mangrove of Paranagua Bay (South-eastern Brazil). Bot. Mar. 34(4): 285-289.

Siddiqui PJA and Qasim R 1988. Changes in dry weight, organic and inorganic content and calorific value in decomposing mangrove, Avicennia marina, foliage. In: MF Thompson and NM Tirmizi (eds) Marine Science of the Arabian Sea. Proceedings of the International Conference, Karachi, Pakistan. 1986. American Institute of Biological Sciences, Washington, D. C. 393-400.

Steinke TD, Naidoo G and Charles LM 1983. Degradation of mangrove leaf and stem tissues in situ in Mgeni estuary, South Africa. In: Teas, H.J. (ed.). Tasks for Vegetation Science 8. DrW. Junk Publishers, The Hague. pp. 141-149.

Stewart BA and Davies BR 1989. The influence of litter bag design on the breakdown of leaf material in a small mountain stream. Hydrobiologia 1983: 173-177.

Strickland JDH and Parson TR 1972. A practical handbook of seawater analysis. Fisheries Research Board of Canada Bulletin No. 167: 310.

Tam NFY, Vrijmoed LIP and Wong YS 1990. Nutrient dynamics associated with leaf decomposition in a small subtropical mangrove community in Hong Kong. Bull. Mar. Sci. 47: 68-78.

Twilley RR, Lugo AE and Patterson-Zucca C 1986. Litter production and turn over in basin mangrove forest in south-west Florida. Ecology 67: 670-683.

(Manuscript received on 6 December, 2012; revised on 14 November, 2013) 